\title{
Pemahaman dan Aplikasi Etika Moral pada Wartawan Media Cetak di Surakarta
}

\author{
Haryanto \\ Program Studi Ilmu Komunikasi \\ Universitas Sebelas Maret Surakarta \\ Email: Haryanto_prodi@staff.uns.ac.id
}

\begin{abstract}
Ethics, in the context of this paper, is synonymous with the rules of communication, that is an understanding of appropriate ways to relate to others based on applicable rules and situations that accompany them. Ethics is not a personal choice but rather a social and cultural desire. As an individual human being can not say at will or do anything he wants without regard to social interests or others. His words and actions must be based on what is deemed appropriate or adequate in the prevailing social system in which he lives. Principles, such as the purpose of justifying the means, the orientation of the goal rather than the means of attaining the goal, are evidence that ethics and morals have not been properly understood and lived properly. This is the central theme in the (report) research, which wants to know the extent to which the moral ethics understanding among print journalists who served in the former Residency of Surakarta. The survey was conducted on 30 journalists selected as sample. From the data collected, it is concluded that: the educational background influences the journalist's understanding of the meaning of "fact, objective and balanced". This difference of understanding, in turn, affects how journalists treat events / events, resource persons and news subjects, in their efforts to create "news value".
\end{abstract}

Keywords: ethics, communication, journalist

\begin{abstract}
Abstrak
Etika, dalam konteks tulisan ini, sinonim dengan aturan komunikasi, yaitu sebuah pemahaman mengenai cara-cara yang layak untuk berhubungan dengan sesama berdasarkan aturan yang berlaku dan situasi yang menyertainya. Etika bukan merupakan pilihan personal akan tetapi lebih merupakan keinginan sosial dan kultural. Sebagai individu manusia tidak bisa mengatakan sekehendak hati atau melakukan apa saja yang ia inginkan tanpa memperhatikan kepentingan sosial atau orang lain. Katakata dan tindakannya harus didasarkan pada sesuatu yang dianggap sesuai atau memadai di dalam sistem sosial yang berlaku, dimana ia hidup. Prinsip-prinsip, seperti tujuan menghalalkan cara, orientasi pada tujuan ketimbang pada cara pencapaian tujuan, merupakan bukti bahwa etika dan moral belum betul-betul dipahami dan dihayati dengan benar. Inilah yang menjadi tema sentral dalam (laporan) penelitian, yaitu ingin mengetahui sejauh mana pemahaman etika moral di kalangan wartawan media cetak yang bertugas di eks Karesidenan Surakarta. Survey dilakukan terhadap 30 orang wartawan yang terpilih sebaga sampel. Dari data yang terkumpul diperoleh kesimpulan bahwa: latar belakang pendidikan mempengaruhi pemahaman wartawan terhadap makna "fakta, obyektif dan seimbang".
\end{abstract}


Perbedaan pemahaman ini, selanjutnya, mempengaruhi bagaimana wartawan memperlakukan peristiwa/kejadian, nara sumber dan subyek berita, dalam upaya mereka menciptakan "news value".

Kata Kunci: Etika, Komunikasi, wartawan

\section{Pendahuluan}

Journalism ethics:

is a species of applied (professional) ethics. It is the application and evaluation of the principles and norms that guide journalism practice, with special attention to the most important problem in the field. Journalism ethics contains both applied analysis and theory. In the analysis of specific cases, journalism ethics may appeal to the theoretical matters, such as the nature of ethical assertion.

Demikian penjelasan Stephen J.A. Ward (2009) tentang etika jurnalistik dalam tulisannya yang berjudul "Applied Journalism Ethics". Ia menjelaskan dengan gamblang fungsi dan posisi etika dalam praktek jurnalistik. Kutipan tersebut di atas sekaligus memberikan penegasan kepada kita betapa pentingnya "etika" dalam kehidupan sosial manusia sehari-hari. Pertanyaannya adalah apa sebenarnya yang dimaksudkan dengan etika. Berikut ini disajikan kutipan definisi, yang dikembangkankan oleh National Scholastic Press Association (NSPA), tentang etika:

The term ethics comes from the Greek word "ethos," which means character. An ethical person is a person of good character who strives to make "right" choices. Those "right" choices are self-determined by each individual. Ultimately, ethics is voluntary conduct that is self-enforced. Although ethics is related to law, it differs from law in that law is socially determined and socially enforced. Law tells us what we can do; ethics, what we should do. What is legal may not be what is ethical. Having the right to say something doesn't make it right to say it

Menurut Franz Magnis-Suseno (1984:6) etika dalam arti yang sebenarnya merupakan falsafah moral, arttinya etika merupakan manifestasi moral seseorang. Selanjutnya ia menjelaskan secara lebih operasional bahwa etika merupakan keseluruhan norma, aturan, sopan-santun, adat-istiadat yang berlaku dalam sebuah komunitas yang mendasari perilaku keseharian para anggotanya, bagaimana mereka saling berhubungan dan berinteraksi, baik secara internal maupun eksternal. Etika merupakan sesuatu yang mendasari seseorang untuk melakukan sesuatu atau tidak melakukan sesuatu.

Sedangkan moral merupakan perpaduan atau kesatuan norma yang bersifat komprehensip, ekstensip dan turun-temurun. Moral merupakan instrument atau ukuran praktis bagi perilaku orang yang tergabung dalam sebuah kelompok atau komunitas. Disadari atau tidak, tertulis atau tidak, moral selalu ada dan dibutuhkan oleh masyarakat (Pasquali, dalam Christians, 1997: 28)

Dalam bukunya yang berjudul Ethics in Media Communication, Louis Alvin Day (2000) menjelaskan bahwa moral berasal dari bahasa Latin mos, moris yang berarti "way of life" atau conduct, yang seringkali berkaitan dengan kepercayaan atau perilaku personal. Sedangkan etika berasal dari bahasa Yunani ethos, yang berarti custom, usage atau character, yang dikenal sebagai proses penerapan prinsip-prinsip yang sudah dikembangkan atau diakui secara rasional pada saat dua atau lebih obligasi moral harus diputuskan.

Persoalan serius akan muncul pada 
saat terjadi konflik antara dua obligasi moral tentang "hak". Persoalan etika muncul sebagai upaya atau proses untuk menseimbangkan antara keinginan memperoleh "hak" dengan tidak mengorbankan "hak" orang lain. Etika selayaknya merupakan referensi dasar untuk memperjuangkan hak apabila tidak ditemukan jawaban yang memuaskan.

Dalam pandangan pesimistik, etika masih merupakan cita-cita yang perlu diwujudkan. Prinsip-prinsip sistem moral masih tergantung di angan-angan dan masih menjadi obyek pengamatan, belum menjadi inspirasi positif bagi keabsahan tindakan manusia (Moemeka, dalam Christians, 1997: 170). Prinsip-prinsip, seperti tujuan menghalalkan cara, orientasi pada tujuan berbanding dengan cara pencapaian tujuan, merupakan bukti bahwa etika dan moral belum betul-betul dipahami dan dihayati dengan benar.

Persoalan inilah yang menjadi permasalahan pokok dalam penelitian ini, yaitu bagaimana pemahaman dan penghayatan para jurnalis, khususnya wartawan anggota Persatuan Wartawan Indonesia (PWI) yang bertugas di Eks Karesidenan Surakarta. terhadap prinsip-prinsip etika moral dalam menjalankan profesi mereka.

Sekalipun masih merupakan anganangan, Moemeka (dalam Christians, 1997: 111) menjelaskan bahwa etika sinonim dengan aturan komunikasi, yaitu sebuah pemahaman mengenai cara-cara yang layak untuk berhubungan dengan sesama berdasarkan aturan yang berlaku dan situasi yang menyertainya. Etika bukan merupakan pilihan personal akan tetapi lebih merupakan keinginan sosial dan kultural. Manusia tidak bisa mengatakan sekehendak hati atau melakukan apa saja yang ia inginkan tanpa memperhatikan kepentingan sosial atau orang lain. Kata-kata dan tindakannya harus didasarkan pada sesuatu yang dianggap sesuai atau memadai di dalam sistem sosial yang berlaku serta dimana manusia itu berada.

Etika dan moral berakar pada kebudayaan atau culture, yang dimasifestasikan dalam bentuk kebiasaan nature. Sekalipun akar etika dan moral bersifat umum untuk ukuran komunitas atau sistem sosial (budaya) setempat namun dalam aplikasinya sangat subyektif., yaitu, sangat tergantung pada pemahaman dan penghayatan seseorang atas sistem nilai budaya yang mereka kembangkan sendiri.

Setiap orang mempunyai pemahaman tersendiri (bisa sama, hampir sama, atau berbeda) mengenai "apa yang etis atau tidak etis, mana yang bermoral atau tidak bermoral", sekalipun mereka mempunyai referensi cultural yang sama. Diskusi dan pembahasan yang mengarah pada generalisasi tentang "apa yang seharusnya disiarkan dan apa yang seharusnya tidak disiarkan" seringkali mendorong munculnya "tension" ketimbang "enlightment", karena ada kecenderungan pada penonjolan perjuangan kebebasan pers, bukannya pada upaya bagaimana merumuskan prinsip-prinsip proses etika-moral (Day, 2000: 53).

Keputusan atau kebijakan yang terlalu menonjolkan kepentingan kebebasan pers kurang mempunyai dasar-dasar pertimbangan moral. Keputusan yang didasarkan pada pertimbangan yang berimbang antara "hak menyiarkan" dan "hak privasi/sosial" orang lain sarat dengan etika moral. Praktek demikian yang seharusnya dikembangkan dalam memperjuangkan kebebasan pers. Artinya, bukan hanya tujuan semata yang menjadi kepentingan utama, akan tetapi cara dan prosesnyapun perlu diperhatikan.

Menurut Day (2000: 53) alasan atau pertimbangan moral (moral reasoning) merupakan pendekatan yang sistematis untuk mewujudkan keputusan yang etis. Selanjutnya ia menjelaskan bahwa moral reasoning membutuhkan proses intelektual sebagaimana terjadi dalam proses intelektual yang lain. Morale reasoning membutuhkan persuasi dan argumentasi yang logis. Alasannya adalah karena jastifikasi etis melibatkan kepentingan dan hakhak orang lain. Oleh karenanya setiap keputusan yang berkaitan dengan masalah etika harus bisa dipertanggung-jawabkan melalui analisis situasi secara mendasar. Seorang yang kurang berpendidikan, mungkin saja akan mengatakan 
bahwa persoalan "kelakuan etis" tidak lebih dari opini belaka.

Dalam halini, Day(2000:53) menjelaskan bahwa morale reasoning bukan hanya sekedar menawarkan tindakan, opini, atau kepercayaan. Morale reasoning merupakan proses yang terstruktur, merupakan proses intektual untuk mempertahankan ethical judgement, berdasarkan kritikan atau masukan dari pihak lain. The beauty of morale reasoning lies in the journey, not in the destination" sebuah ungkapan yang sangat indah sekaligus menggambar-kan bagaimana proses validasi morale reasoning seharusnya terjadi. Persoalannya saat ini menjadi jelas bahwa etika atau moral tidak akan muncul dengan tiba-tiba. Etika atau moral seseorang akan berkembang seiring dengan proses pendewasaan penalaran masing-masing pribadi. Ini mengandung makna bahwa pendidikan baik formal maupun non formal memegang peranan yang sangat penting.

Dalam penelitian ini dikaji apakah latarbelakang pendidikan seorang jurnalis mempunyai perbedaan terhadap profesionalisme mereka dalam melaksanakan tugas-tugas jurnalistik. Kajian tentang profesionalisme waartawan akan difokuskan pada ketaatan jurnalis terhadap general code of conduct di bidang jurnalistik dan pemahaman, penghayatan dan aplikasi etika moral dalam menjalankan fungsi jurnalistiknya. General code of conduct merupakan referensi umum, yang tertuang dalam Undang Undang Pokok Pers dan atau Kode etik Jurnalistik yang diterbitkan oleh Persatuan Wartawan Indonesia (PWI).

Dalam sistem pendidikan komunikasi jurnalisitik di Indonesia, materi-materi yang berkaitan dengan general code of conduct, sudah menjadi bagian dari kurikulum inti. Artinya bahwa alumni program studi komunikasi jurnalistik, diasumsikan, sudah paham atau sekurang-kurangnya sudah dibekali dengan materi-materi etika profesi. Akan tetapi wartawan, sebagai sebuah profesi, juga banyak diminati orang dari berbagai disiplin ilmu.

Fakta menunjukkan bahwa menjadi seorang reporter, presenter ataupun jurnalis yang terkenal bukan pekerjaan yang sulit, namun menjalankan profesi tersebut secara santun, berbudaya dan elegan bukanlah pekerjaan yang mudah. Profesi sebagai wartawan memerlukan wawasan dan pengalaman yang luas. Latar belakang pendidikan diasumsikan memberikan kontribusi yang cukup signifikan, sehingga para jurnalis lebih cenderung mengejar aktualita dan daya tarik ketimbang mempertimbangkan dampak sosial yang mungkin ditimbulkan akibat pemberitaan yang mereka lakukan.

Demi mengejar aktualita, daya tarik dan batas waktu penyiaran/penerbitan wartawan/ jurnalis, seringkali, mengabaikan faktor akurasi. Keluhan Presiden RI Susilo Bambang Yudhoyono, ketika terkena diary saat berkunjung di luar Jawa beberapa waktu yang lalu, merupakan contoh yang konkrit. Akibat ketidak-akuratan wartawan, terpaksa Presiden harus melakukan klarifikasi agar tidak menimbulkan kesimpangsiuran di masyarakat. Fenomena ini merupakan "indikasi" betapa lemahnya pemahaman dan praktek etika/ moral profesi kewartawanan.

Adalah hak setiap warga negara (termasuk di dalamnya Jurnalis) untuk mencari, mendapatkan dan menyiarkan informasi secara terbuka, jujur dan adil/berimbang. Hal ini dijamin dan dilindungi oleh peraturan perundangan yang berlaku. Ini merupakan kodrat manusia sebagai makhluk sosial.

Salah satu dimensi konsep kekebasan pers yang berlaku hampir di seluruh dunia adalah "hak publik/rakyat untuk mengetahui hal ikhwal yang berkaitan dengan penyelenggaraan Negara". Atas nama publik/rakyat, jurnalis berburu informasi/ berita dengan menggunakan sumber pemerintah atau non pemerintah, baik secara kelompok maupun individual, untuk kemudian disiarkan secara masal, agar masyarakat bisa melakukan kontrol sosial.

Persoalannya bukan pada "hak untuk menyiarkan", akan tetapi terletak pada dampak atau akibat yang ditimbulkan oleh siaran tersebut. Seringkali akibat yang ditimbulkan tidak seperti yang diharapkan, sehingga maksud hati memberikan pencerahan kepada publik, 
namun kebingunan yang didapat. Persoalan yang muncul adalah bahwa seringkali terjadi perbedaan konsep dan pemahaman mengenai: "apa yang dianggap penting dan perlu diketahui oleh publik". Dengan alasan tertentu, dampak pemberitaan kurang begitu mendapatkan perhatian. Di sini isu tentang etika/moral menjadi sangat signifikan, yaitu memutuskan "menyiarkan atau tidak menyiarkan" dengan mempertimbangkan dampak yang mungkin timbul akibat keputusan tersebut.

Isu tentang etika/moral menjadi tema sentral penelitian ini; yaitu mengkaji atau menelaah "seberapa jauh pemahaman/ penghayatan jurnalis terhadap persoalan etika moral, baik yang bersifat yuridis formal maupun yang berupa tata nilai yang berlaku dan berkembang di masyarakat kita, yang tertuang dalam karya jurnalistik mereka?. Fokus utamanya akan ditekankan pada "apakah perbedaan latar belakang pendidikan (disiplin komunikasi/ jurnalistik dan non komunikasi) berpengaruh terhadap pemahaman dan penghayatan etika/ moral dimaksud?

Sebenarnya pelaksanaan kebebasan pers di Indonesia masih dalam batas kewajaran, hanya saja waktu atau suasananya kurang tepat/mendukung, sehingga ada kalangan yang menganggap pers kita sudah "kebablasan". Ada indikasi, agaknya pers Indonesia terseret arus pusaran elite politik yang sedang berebut kepentingan, pengaruh dan kekuasaan. Pada satu sisi elite politik membutuhkan media massa untuk aktualisasi diri dan memperjuangkan kepentingan politiknya, pada sisi lain, dalam waktu yang bersamaan, media massa seperti orang yang baru bangun tidur, lantaran selama 32 tahun terbelenggu kebebasannya. Sebagai akibatnya, pers kurang bisa membedakan mana yang merupakan kepentingan publik dan mana yang merupakan hak politik pers.

Isu ini menjadi semakin krusial karena sebagian besar konflik politik/kepentingan yang dipicu atau di-amplified oleh siaran pers banyak menguras energi masyarakat, dimana masyarakat perlu mensinergikan gagasan dan upaya agar bisa segera lepas dari krisis ekonomi/moneter yang berkepanjangan. Dibutuhkan suasana politik yang kondusif agar upaya mensejahterakan kehidupan bangsa segera terwujud.

Praktek kebebasan pers di Indonesia mempunyai andil yang cukup signifikan terhadap terciptanya situasi yang kurang kondusif - Mungkin karena terlalu mengedepankan unsur "kekinian" dan larut dalam pusaran arus perhelatan politik nasional, pers nasional yang diharapkan mampu memberikan pencerahaan kepada publik justru sebaliknya yang terjadi. Masyarakat menjadi bingung dibuatnya. Setiap detik, menit, jam dan hari senantiasa disodori berita/informasi politik, yang belum tentu bisa dipahami dan dicerna oleh sebagian besar masyarakat Indonesia. Sebagai akibatnya bukan pencerahaan yang mereka peroleh, sebaliknya kebingungan dan kegelapan yang mereka dapat. Harus diingat bahwa "freedom of the press is not a destination. Freedom of the press is a tool or vehicle to seek or reach the truth".

Isu utama dalam penelitian ini, yaitu mengumpulkan bukti-bukti empirik "seberapa jauh latar belakang pendidikan berpengaruh terhadap pemahaman dan penghayatan etika moral di kalangan wartawan media cetak yang bertugas di eks Karesidenan Surakarta? Secara akademis nilai signifikansi penelitian ini sangat tinggi, karena akan bermanfaat bagi perbaikan kurikulum pendidikan formal bidang jurnalistik, utamanya yang berkaitan dengan pengembangan/perumusan materi Mata Kuliah Etika Komunikasi.

A journalist must be open-minded
to other people, to other reasons
and to other cultures, tolerant and
humanitarian. There should be not
room in the media for those people
whouse them to sow hate and hostility,
and to advertise. The problem of our
profession is an ethical matter.

Barroso (2006) menyatakan mengenai pentingnya etika bagi seorang jurnalis dalam menjalankan tugasnya, yang dituangkan 
dalam laporan penelitiannya berjudul "Movie: a powerfull resource of visual literacy in journalism ethics". Salah satu kesimpulan penting yang dirumuskan oleh Barroso dan relevan dengan konteks penelitian ini adalah: "the journalist must have a moral and ethical preparation, being the Professional Ethics the guideline of his/her journalistic praxis"

Kesimpulan tersebut, secara tidak langsung, menyiratkan pentingnya pendidikan dalam rangka menyiapkan dan membekali pemahaman etika moral bagi para calon jurnalis atau jurnalis muda. Pembekalan bagi calon jurnalis adalah penting, karena jurnalis mengemban tiga tugas mulia (Ward, 2009):

1. General ethical duties: seperti halnya anggota masyarakat yang lain, seorang jurnalis sudah selayaknya patuh terhadap prinsip-prinsip etika umum, seperti: jujur, menepati janji, menghindari perselisihan dan melayani publik dengan baik. Sayangnya prinsip-prinsip ini diterjemahkan secara berbeda dalam pelaporan dan editing.

2. Journalism's social role: seperti para professional lain, jurnalis menggunakan keahlian mereka untuk memenuhi peranan sosialnya dan harapan publik. Peranannya, kadang-kadang dipahami sebagai bagian dari kontrak sosial antara journalisme dan masyarakat. Di kebanyakan Negara Barat, jurnalis diberikan kebebasan yang dilindungi undang-undang dalam rangka perbaikan kondisi sosial, misalnya diberikan kebebasan dalam hal berbeda pendapat/ pandangan dan kebebasn melakukan analisis terhadap kejadian secara komprehensif.

3. Impact and influence: jurnalis harus bertanggung jawab secara etis atas akibat yang ditimbulkan oleh laporan yang dibuatnya baik terhadap individu maupun kelompok, sekecil apapun akibat yang ditimbulkannya.
Tiga fungsi utama tersebut memperkuat alasan mengenai nilai pentingnya pembekalan etika moral bagi calon jurnalis. Adapun tujuan utama pembekalan tersebut seharusnya ditekankan pada hal-hal sebagai berikut (Ward: 2009), (1) Understanding: memperdalam pemahaman tentang fungsi dan prinsipprinsip etika journalism, (2) Ethical reasoning: meningkatkan kemampuan dialektika personal, sosial dan kultural dalam rangka membangun ethical reasoning di kalangan para calon jurnalis, (3) Reforming: senantiasa memperbaiki standar atau prinsip-prinsip etika yang sudah ada, (4) Promoting: senantiasa memperbaiki perilaku etis dan decision making berkaitan dengan pemberitaan media, (5)Discussion: mendorong dan meningkatkan diskusi publik tentang etika journalism.

Poin-poin tersebut merupakan guideline yang seharusnya diarahkan dalam pengajaran etika-moral jurnalistik untuk memberikan ruang bagi para calon jurnalis dalam mengenali obligasi moral dan agar terbiasa melakukan dialektika morale reasoning, maka beberapa pelanggaran umum yang biasa dilakukan oleh jurnalis berikut ini sudah selayaknya mendapatkan ekstra perhatian, yaitu (Ward: 2009):

a) Accuracy and verification: masaalah ini menyangkut seberapa banyak buktibukti pendukung yang dibutuhkan/ diperlukan untuk menyiarkan berita? Kemana, kepada siapa, dan seberapa banyak verifikasi harus dilakukan?

b) Context: Apakah jurnalis memberikan atau menyertakan konteks yang tepat terhadap fakta-fakta yang mereka kumpulkan? Apakah konteks yang mereka bangun layak terhadap fakta yang ditemukan?

c) Deception and fabrication: Pantaskah jurnalis menyamar atau menggunakan kamera tersembunyi?

d) Graphic images and sensationalism: Kapan seharusnya jurnalis menyertakan gambar-gambar yang menyeramkan? Kapan images bisa menimbulkan rasa 
bersalah, sensasi atau eksploitasi? Kapan images menjadi tidak proporsional atau menjadi berlebihan?

e) Illegal acts: Pantaskah jurnalis harus melanggar aturan untuk mendapatkan data, fakta, atau cerita?

f) Source and confidentiality: Pantaskah jurnalis menjanjikan "kerahasiaan" terhadap sumber berita? Pantaskah jurnalis menolak menunjukkan sumber berita kepada polisi atau pengadilan? Kapa seharusnya jurnalis mematuhi "off the record"?

g) Special sensitive situation: Bagaimana seharusnya jurnalis memperlakukan/ menyikapi peristiwa pembebasanpenyanderaan; usaha bunuh diri; atau kejadian-kejadian lain dimana pemberitaan media dapat memperburuk keadaan, atau akan menimbulkan konsekuensi pada rutinitas kehidupan masyarakat?

Tujuh poin tersebut merupakan sisi-sisi dimana seorang jurnalis mudah sekali terjebak dalam problematika etika-moral, yang bisa terjadi karena disengaja atau tidak disengaja. Hal ini dimungkinkan karena persoalan ini merupakan masalah pilihan; yaitu pilihan melakukan atau tidak melakukan, pilihan menyiarkan atau tidak menyiarkan. Persoalannya sekarang adalah: apa yang menjadi dasar pertimbingan atas pilihan tersebut? Apakah pilihan yang diambil dilakukan secara sadar/disengaja atau tidak? Berikut ini disajikan beberapa factor yang diperkirakan mempengaruhi jurnalis dalam menentukan pilihan atau memaksa jurnalis untuk memilih Ward: 2009):

\section{Proliferation of news media:}

a) Meningkatnya kompetisi di antara provider berita

b) Tekanan memperoleh "materi" untuk mengisi programbaru

c) Banyak media memaksakan membuat "story of the day"
2. Changes in news media audiences:

a) Fragmentasi audience: demografi yang lebih kecil, persaingan media

b) Kebutuhan berita segar yang lebih kuat: siaran langsung dsb.

c) Hasrat audience yang selalu meningkat untuk akses berita/foto, meskipun belum diverifikasi secara lengkap.

d) Tidak sabar: audience jarak jauh

e) Hasrat audience untuk berinteraksi dengan media.

3. Convergence of news media:

a) Lembaga pemberitaan berusaha merangkul audience lintas platform media

b) Jurnalis cenderung bekerja pada beberapa media (multimedia newsrooms).

c) Korporasi global news melalui merger atau akuisisi.

4. Meningkatnya nilai bisnis:

a) Berita sebagai bagian dari produk usaha atau profit-driven corporation.

Ke-empat faktor tersebut merupakan realita sosial yang tidak bisa dihindari kemunculannya, hal ini merupakan dampak langsung dari globalisasi masyarakat dunia, akiibat aplikasi teknologi komunikasi dan informasi di bidang industri media massa; serta sebagai akibat perubahan struktur dan sistem sosial karena tuntutan globalisasi. Peneliti ingin menggaris-bawahi bahwa ada wilayah-wilayah dimana jurnalis bisa terjebak dalam pelanggaran etika-moral dan probabilitas terjadinya pelanggaran tersebut ada pada diri jurnalis sendiri. Banyak faktor yang bisa menyebabkan jurnalis terjebak dalam problematika etika moral, yaitu: proliferasi pemberitaan media, perubahan audience media, konvegensi pemberitaan antar media, dan tuntutan bisnis media.

Beberapa dampak positif dari perubahan antara lain ; peluang interaksi antara publik dengan media lebih besar, akses informasi lebih mudah, dengan jangkauan lebih luas, Bisa 
mengurangi fungsi dan peranan gatekeeper, Munculnya metode story-telling baru lewat media, Konvergensi pemberitaan bisa mengarah pada penjelasan isu/kejadian secara lebih komprehensip. Beberapa dampak negatifnya, adalah, jurnalis cenderung memasukkan opini untuk menarik perhatian audience, tanpa verikasi, kurang obyektif, lebih sensasional, dan cenderung memperburuk kondisi konflik, cenderung mengabaikan etika-moral: penyederhanaan isi, konteksnya dihilangkan, analisis lemah. Lebih menonjolkan berita selebriti dan hiburan, Banyak keluhan mengenai pelanggaran privasi, berlebihan, Kecenderungan konvergensi dan nilai bisnis: perhatian terhadap keragaman berita, pengaruh korporasi media global, lebih menekankan pada kepentingan ekonomi ketimbang kepentingan etika, konflik kepentingan, kurangnya jurnalis independent, Kebingunan publik: siapa sebenarnya jurnalis sungguhan, apa kriterianya sebagai jurnalis sungguhan.

Sebagai antisipasi terhadap perangkat terjadinya pelanggaran etika-moral, Ward (2009) menawarkan sebuah model analisis agar supaya jurnalis tidak terjebak dalam perangkap tersebut:

1. Kesadaran bahwa terdapat persoalan etika di dalam pemberitaan: apabila ada situasi dimana tidak ada kepastian, ketidak-jelasan yang mengarah pada perbedaan pandangan mengenai apa yang harus/seharusnya dilakukan.

2. Lakukan analisis terhadap kasus tersebut:
a) identifikasi isu-isu etika yang mungkin terkandung di dalamnya;
b) identifikasi nilai-nilai yang bertentangan dan
c) identifikasi fakta-fakta yang paling relevan.

3. Evaluasi dan pertimbangan alternative keputusan yang mungkin:
a) identifikasi premis-premis etis yang mungkin;
b) pertimbangkan konsekuensinya;
c) pertimbangkan hak/kuajiban sebagai

jurnalis;

d) pertimbangkan dampaknya terhadap reputasi pribadi maupun profesi.

e) Pilih tindakan yang tepat setelah mempertimbangkan segala sesuatunya.

f) Rumuskan justifikasi etis mengenai alasan, prinsip-prinsip yang mendasari pilihan, agar siap apabila ada keluhan atau kebaratan dari pihak lain.

4. Laksanakan tindakan/keputusan, dan lakukan review terhadap tindakan tersebut di kemudian hari: pelajarifeedback-nya, karena feedback sangat penting untuk perbaikan keputusan etis selanjutnya. Mana yang tepat dan mana yang perlu diperbaiki.

Jurnalis bisa mengembangkan "check list" sendiri dan memanfaatkan feedback yang disampaikan oleh siapapun yang merasa dirugikan atas pemberitaan yang dibuat, yang disebut proses "dialectical moral reasoning". Apabila dialektika ini dilakukan terus-menerus maka pada titik tertentu seorang jurnalis akan menemukan apa yang disebut "personal code of conduct" yang akan mengarah pada terbentuknya "self-governing morale" bagi jurnalis . Ethical codes dibutuhkann untuk mengawal terwujudnya kebebasan pers: yang mempunyai nilai tanggung jawab sosial, membantu mewujudkan kesejahteraan sosial dan mempercepat proses demokrasi. Persoalannya kemudian "siapa yang bertanggung jawab dan bagaimana melakukannya?"

Dalam sistem pendidikan di Indonesia, materi etika jurnalistik terangkum dalam mata kuliah Etika dan Filsafat Komunikasi, Hukum dan media massa. Mata kuliah tersebut menempatkan aspek legal-formal sebagai materi utamanya. Ada beberapa perguruan tinggi yang menyisipkan muatan etika pada mata kuliah "Teknik Penulisan Berita" atau yang sejenis. Melalui observasi dan diskusi dengan pengampu mata kuliah tersebut, diketahui bahwa materi legal formal seperti: Undang Undang Pokok Pers, Undang Undang Penyiaran, Kode Etik Wartawan Indonesia, dan sejenisnya mendominasi materi 
kuliah secara keseluruhan.

Dari sisi teknis, “ceramah" banyak dipakai sebagai metode utama dalam penyampaian materi kuliah. Masih sangat jarang yang menggunakan "studi kasus" sebagai metode atau teknik pembelajaran. Peneliti pesimis bahwa jurnalis muda mempunyai dasar-dasar etika moral yang kuat dalam menjalankan profesinya, karena dinamiika persoalan etika moral yang telah mengalami diversifikasi yang luar biasa sejalan dengan perkembangan industri media massa sebagai akibat dari aplikasi teknologi informasi dan komunikasi, Sebagaimana diperlihatkan dalam sejarah perkembangan etika jurnalisitik, Gambar 1). Harus diingat bahwa mengajarkan etika journalism tidak cukup hanya dengan transfer teori dan konsep, tetapi juga harus mampu mendorong dan memotivasi mahasiswa menjadi "critical thinker", menjadi pemikir yang kritis dan kreatif. Penegasan ini sesuai dengan karakter "etika journalism" sendiri, yaitu sebagai "science" dan sekaligus sebagai "art"

Berkaitan dengan persoalan ini, UNESCO (2004) mensponsori sebuah seminar international, yang melibatkan Program Studi Jurnalisitik dan Komunikasi Massa di dunia yang tergabung dalam Journalism Network (JourNet), dengan tema "teaching journalism", dan salah satu model pembelajaran yang mendapatkan perhatian terbesar adalah " $A$ reflective model for teaching journalism".

Model ini memfokuskan pada:

“... the development of graduate efficacy in the intellectual skill and understanding required of professional practitioners. The model uses critical reflection as a cognitive bridge between journalism theory and professional practices. Through it, students develop selfreliance, confidence, problem solving, and adaptability, while simultaneously gaining knowledge and developing a sense of efficacy in their ability to negotiate inherent dilemmas in practice. When pedagogical strategies "block the exits" to escape from the implications and effects of their practice, students are held to high benchmarks of critical and reflective thinking. The "lived" experience provided by a problem-based pedagogy also develops confidence and sense of efficacy in students. Moreover, this approach integrates thinking and doing in a way that binds practices with the social and ethical effects produced.

Dengan demikian menjadi jelas 'bagaimana seharusnya mengajarkan etika journalism, sehingga para jurnalis muda mempunyai kebiasaan sebagai reflective and critical thinker".

Pertanyaan berikutnya adalah "siapa yang layak mengajarkan materi etika jurnalistik, apakah ahli filsafat ataukah praktisi media? memperhatikan sistem pendidikan nasional maupun internasional, Filsafat dan Etika diajarkan di hampir setiap Negara di dunia dan di hampir semua Program Studi. Akan tetapi siapa yang berani menjamin bahwa semua alumni berperilaku etis sebagaimana digariskan dalam proses pembelajaran? Hal ini berarti bahwa ahli filsafat tidak serta merta mampu membekali calon jurnalis mampu menjalankan profesinya sebagaimana yang diharapkan. Sebaliknya praktisi media diduga kurang mampu dalam memberikan bekal teori dialektika moral, yang seharusnya menjadi rujukan bagi jurnalis pada saat mereka dihadapkan pada obligasi moral yang kompleks.

Etika jurnalisitik merupakan science sekaligus art, sehingga harus ada keseimbangan antara bekal teori dan praktis, dimana dalam sejarah etika jurnalisitik (lihat Gambar 1), dapat dilihat bahwa lahirnya etika jurnalisitik beriringan dengan evolusi atau perkembangan teori kebebasan pers, sehingga idealnya pengajar etika jurnalisitik adalah ahli filsafat dan praktisi media.

Realita menunjukkan bahwa profesi jurnalistik banyak diisi oleh orang-orang dari beragam disiplin ilmu bukan hanya dari disiplin ilmu Jurnalistik dan Komunikasi Massa" saja. 
Gambar 1: History of Journalism Ethics

\begin{tabular}{|l|l|l|}
\hline & \multicolumn{2}{|l|}{ Authoritarian theory of the press $\left(17^{\text {th }}\right.$ century) } \\
\hline & \multicolumn{2}{|l|}{ Public theory $\left(18^{\text {th }}\right.$ century) } \\
\hline & \multicolumn{2}{|l|}{ Liberal theory $\left(19^{\text {th }}\right.$ century) } \\
\hline $\begin{array}{l}\text { Elite liberal } \\
\text { Reformed by opinion } \\
\text { interpretation }\end{array}$ & \multicolumn{2}{|l|}{$\begin{array}{l}\text { Egalitarian liberal } \\
\text { Reformed by news fact }\end{array}$} \\
\hline & $\begin{array}{l}\text { Interpretation vs objectivity } \\
\left(20^{\text {th }} \text { century) }\right.\end{array}$ & \\
\hline $\begin{array}{l}\text { Muckraking } \\
\text { interpretative journalism } \\
\text { Broadcast media }\end{array}$ & $\begin{array}{l}\text { Ethics on the global, digital } \\
\text { frontier }\left(21^{\text {th }} \text { century). }\right.\end{array}$ & Objective reporting \\
\hline & $\begin{array}{l}\text { On-line, inter media, global } \\
\text { media }\end{array}$ & \\
\hline & Global journalism ethics? & \\
\hline & & \\
\hline
\end{tabular}

\section{Sumber: Ward (2009)}

Sehingga menambah kompleksitas dan ragam persoalan etika jurnalistik. Peneliti mencoba mengkaji "perbedaan latar belakang pendidikan dan profesionalisme jurnalis dalam menjalankan fungsinya". Dalam penelitian ini latar belakang pendidikan dibedakan dalam: Alumni jurnalistik/ komunikasi dan non-jurnalistik/komunikasi, bekerja sebagai jurnalis di media cetak, dan memegang Kartu Identitas sebagai anggota Persatuan Wartawan Indonesia (PWI).

\section{Metode Penelitian}

Populasi dari penelitian ini adalah wartawan atau jurnalis media cetak, yang menjadi anggota PWI dan bertugas atau mempunyai wilayah kerja di eks karesidenan Surakarta. Menurut data keanggotaan PWI Pusat Jakarta yang berhasil diunduh, wartawan anggota PWI yang mempunyai wilayah kerja di Surakarta ada sebanyak : 193 orang, yang terdiri dari 29 anggota muda, 93 keanggotaannya belum diperpanjang dan 71 orang yang masih menjadi angota PWI aktif. Dengan jumlah tersebut maka diputuskan sampel penelitian adalah sebesar 30 orang.

Penetapan jumlah 30, semata-mata didasarkan alasan teori kurve normal, dengan teknik sampling yang digunakan adalah purposive random sampling; dengan pertimbangan utamanya adalah:

a) Penelitian ini berkaitan dengan etika jurnalistik; bahwa jurnalis harus mengembangkan rasa tanggung jawab sosial di atas "hak siar".

b) Oleh karenanya dipilih sampel jurnalis yang bekerja pada media massa dengan sirkulasi yang lebih besar, baik local, regional, maupun nasional.

c) Berdasarkan hal tersebut dipilih harian Solo Pos, Jawa Pos; Radar Solo, Suara Merdeka, 
Kompas, Bisnis Indonesia dan Sindo, ditetapkan sebagai institusi tempat bekerja jurnalis yang dijadikan sampel penelitian.

Pengukuran terhadap profesionalisme jurnalis akan didasarkan pada 18 item yang dikembangkan oleh David E. Sumner (professor journalism dari Universitas Ball State, Amerika), dengan beberapa modifikasi.

\section{Hasil dan Pembahasan}

Responden dalam penelitian ini terdidi dari 11 waratawan laki-laki dan 19 wartawan wanita, dengan variasi umur kurang dari 30 tahun $30 \%, 30-40$ tahun 50\% dan lebih dari 40 $\%$ sebayak 20\%. Dilihat dari sisi umur sudah selayaknya responden mempunyai tingkat kedewasaan yang cukup.

Selain itu, juga masih dalam tingkat produktifitas yang tinggi, mengingat usia di bawah 40 tahun adalah usia produktif. Wartawan yang dijadikan responden memiliki masa kerja kurang dari 10 tahun sebanyak 30\%, 10-20 tahun sebanyak \#\& \% dan lebih dari 29 tahun sebanyak $33 \%$, sehingga rata-rata jurnalis yang menjadi responden memiliki cukup berpengalaman. Hal ini terlihat dari masa kerja mereka yang sudah cukup lama.

Sedangkan yang memiliki latar belakang Jurnalisitik atau Komunikasi sebanyak $80 \%$ dan yang berasal dari disiplin ilmu yang lain sebanyak $20 \%$. Sekalipun jumlahnya relative sedikit, ternyata profesi sebagai seorang jurnalis tetap diminati oleh para alumni yang berasal dari disiplin ilmu di luar jurnalistik atau komunikasi massa. Untuk jenis pelatihan yang pernah diikuti, pelatihan editorial $11 \%$, reportase $15 \%$, manajemen $10 \%$, hukum dan undang-undang $32 \%$ dan etika $32 \%$. sebagian responden sudah selayaknya mempunyai pemahaman tentang hokum dan perundangan-undangan yang berlaku di Indonesia serta etika profesi.

Profesionalisme adalah pelaksanaan tugas dan tanggung jawab sebagaimana yang digariskan dalam code of conduct untuk bidang profesi yang bersangkutan. Sedangkan pengukurannya menggunakan pola 18 item (dengan sedikit modifikasi) yang dikembangkan oleh Prof. David E. Sumner.

Kualitas Berita. Kualitas berita meliputi penilaian terhadap: rumusan dan kemenarikan tajuk/lead, penggunaan kalimat pasif, ketepatan pemilihan kata kerja, dan kesederhanaan/ kejelasan kalimat. Untuk bidang ini diberikan bobot 30. Hasil penilaian terhadap kualitas berita para jurnalis, yang masuk kategori cukup bagus $17 \%$, bagus $20 \%$ dan kurang bagus $63 \%$, sedangkan untuk sangat bagus dan tidak bagus 0 . Hal ini menunjukkan bahwa kualitas berita yang dihasilkan oleh para jurnalis yang menjadi rsponden kurang begitu menggembirakan. Artinya bahwa berdasarkan aspek yang diniai, berita yang mereka tulis mengandung problematika etika-moral. Bahwa apa yang mereka sajikan cenderung memicu terjadinya "harmless", memicu timbulnya friksi dan kontroversi. Hal ini terutama sekali terlihat dalam penggunaan/ pemilihan kata kerja dan bentuk kalimat pasif.

Pilihan kata kerja merupakan tindakan kesengajaan untuk bias mengangkat nilai berita. Dari sisi legal formal perilaku demikian tidak bias disalahkan, akan tetapi mengandung obligasi moral yang mungkin bias memicu terjadinya hal-hal yang kurang baik. Penggunaan kalimat pasif dalam penulisan berita dilakukan untuk mengaburkan atau menyembunyikan subyek berita, yang secara hukum statusnya belum jelas. Dengan cara ini bisa menghindari terjadinya "trial by press" atau pembunuhan karakter.

Kedalaman Isi dan Kualitas Sumber Berita.Untuk kualitas "kedalaman isi dan kualitas sumber berita", meliputi: ketepatan pemilihan sumber, kedalaman isi dan kemenarikan alur cerita, kelayakan/ ketepatan penggunaan data pendukung, serta keseimbangan dan obyektifitas penggunaan nara sumber dan penggunaan bahan berita. Hasilnya menunjukkan bahwa untuka kategori kualitas cukup bagus $23 \%$, bagus 27 $\%$ dan kurang bagus $50 \%$, uantuk kategori sangat bagus dan tidak bagus $0 \%$. Aspek "kedalaman isi dan kualitas sumber" kondisinya juga kurang menggembirakan. Dilihat dari sisi 
"kode etik jurnalistik" hampir-hampir tidak ada pelanggaran. Akan tetapi pada diteliti lebih jauh baru kelihatan problematika etika-moral yang terjadi; yaitu bahwa pilihan sumber berita atau nara sumber terkesan tendensius dan data-data pendukung yang disampaikan kelihatan sudah kehilangan konteks.

Ada kecenderungan pemilihan sumber berita pada orang atau figure yang mempunyai penilaian berseberangan dengan kejadian yang sedang diangkat. Sebagai akibatnya, berita yang diangkat cenderung memperkeruh persoalan ketimbang memberikan enlightenment kepada publik. Kebanyakan data pendukung yang disajikan "sudah dipotong" dengan maksud tertentu. Seringkali pemotongan demikian akan menghilangkan konteks yang dibangun oleh sumber data atau speaker. Akibat perlakukan demikian, pemotongan yang tidak tepat, akan menghasilkan makna yang berbeda. Ini yang oleh sementara sumber berita diklaim sebagai "pemelintiran informasi".

Keaslian, organisasi \& kualitas focus. Aspek ketiga dari penilaian terhadap profesionalisme jurnalis yang menjadi sample penelitian ini adalah "keaslian, organisasi dan kualitas fokus", yang meliputi: keaslian ide dengan fokus angle yang jelas, kejelasan sistematika dan komprehensifitas/kohesifitas. Hasilnya menunjukkan untuk kategori cukup bagus sebanyak $33 \%$, bagus $27 \%$, kurang bagus $40 \%$ dan $0 \%$ untuk kategori sangat bagus dan tidak bagus. Aspek "keaslian, organisasi dan kualitas fokus", menunjukkan masih adanya jurnalis/wartawan yang mengambil materi berita dari sumber-sumber on-line. Ini bukan merupakan pelanggaran, karena sumbernya disebutkan. Akan tetapi dari sisi keaslian/ originalitas mengandung problematika etikamoral.

Mekanik. Mekanik merupakan aspek penilaian ke-empat atau terakhir. Aspek ini meliputi: jumlah kata/volume, kesalahan ketik (satu kesalahan, satu penalty), salah eja (tiga kesalahan satu penalty), tanda baca (satu kesalahan satu penalty), dan salah tata bahasa (satu kesalahan satu penalty). Hasilnya menunjukkan untuk kategori sangat bagus 7 $\%$, cukup bagus sebanyak $30 \%$, bagus $40 \%$, kurang bagus $23 \%$ dan $0 \%$ untuk kategori tidak bagus.hal ini menunjukkan bahwa dari sisi aspek mekanik tidak banyak mengandung persoalan. Aspek ini sebenarnya lebih merupakan aspek teknis ketimbang persoalan etika-moral.

Profesionalisme Jurnalis. Dengan menyatukan hasil dari ke-empat aspek penilaian tersebut di atas, akhirnya diperoleh hasil penilaian "profesionalisme Jurnalis" terhadap jurnalis yang menjadi responden dalam penelitian ini, yaitu menunjukkan untuk kategori cukup bagus sebanyak $27 \%$, bagus $30 \%$, kurang bagus 43 $\%$ dan $0 \%$ untuk kategori sangat bagus dan tidak bagus. Secara keseluruhan hasil penilaian terhadap profesionalisme jurnalis, dengan menggunakan formula Sumner menunjukkan hasil yang kurang memuaskan.

Profesionalisme jurnalis dalam penelitian ini menggunakan formula 18 item sebagaimana dikembangkan oleh Prof. Sumner, yang mendasarkan pada undang undang dan kode etik profesi yang berlaku, serta memberikan bobot lebih pada "personal code of conduct"

General Code of Conduct. Secara umum loyalitas wartawan atau jurnalis yang menjadi sampel penelitian cukup bagus. Artinya hampir tidak ada pelanggaran terhadap kode etik jurnalistik dan peraturan perunsangan yang berlaku di Indonesia. Pelanggaran wajar yang teridentifikasi dalam penelitian ini adalah bahwa wartawan cenderung kurang obyektif dalam memperlakukan kejadian atau peristiwa. Ketidak-obyektifan tersebut muncul diduga karena pengaruh masuknya opini pribadi baik dalam penulisan maupun pemilihan sumber berita.

Penegasan tersebut memang bersifat debatable. Wartawan atau jurnalis masih bias berargumen, karena telah melibatkan lebih dari satu sumber berita (yang merupakan salah satu unsur obyektifitas). Akan tetapi kalau diperhatikan lebih jauh, pemilihan sumbersumber berita yang dilakukan oleh jurnalis 
cenderung "tendensius". Artinya ada maksudmaksud tertentu dibalik pilihannya. Ini yang oleh Peneliti dianggap kurang obyektif.

Hal yang sama juga terjadi dalam penyertaan data atau informasi pendukung. Karena tidak dimungkinkan menyajikan data/ informasi secara utuh, wartawan/jurnalis biasanya memotong bagian-bagian tertentu yang oleh mereka dianggap penting/mendukung cerita/ berita. Namun, sekali lagi karena masuknya opini pribadi, mereka tidak sadar - bisa jadi juga disengaja - bahwa apa yang mereka lakukan justru akan menghilangkan "konteks", yang bias membiaskan makna yang sebenarnya. Sifat faktualnya masih ada, sehingga lepas dari tuntutan hukum. Tetapi dengan hilangnya konteks, sumber beritalah yang dirugikan. Hal demikian akan memperkeruh keadaan dan memicu munculnya "harmless".

Personal Code of Conduct. Dari sudut pandang General Code of Conduct pelanggaran tersebut di atas dianggap ringan. Karena hal
$(1997,139)$ professionalism is a means of control in the news organisations... professionalism acts as a method of control for the managers wishing to make a profit. Professionalism is thus also a way to minimise conflict in the newsroom (profesionalisme merupakan alat control dalam organisasi pemberitaan... profesionalisme bertindak sebagai metode pengendalian terhadap manager yang hanya memburu keuntungan. Profesionalisme juga merupakan cara untuk memperkecil munculnya konflik di ruang redaksi).

Perubahan cukup besar terlihat pada saat "perbedaan latar belakang pendidikan" dihubungkan dengan "loyalitas terhadap personal code of conduct". Bahwa jurnalis yang merupakan alumni non-komunikasi massa cenderung tidak loyal terhadap personal code of conduct. Hal ini bias dipahami mengingat alumni kurang mengenal filosofi profesi jurnalistik secara lebih mendalam.

Tabel 1

Perbedaan Latar Belakang Pendidikan dan Loyalitas terhadap General Code of Conduct

\begin{tabular}{|l|l|l|l|}
\hline \multirow{2}{*}{$\begin{array}{l}\text { Loyalitas terhadap } \\
\text { General Code of } \\
\text { Conduct }\end{array}$} & \multicolumn{2}{|l|}{ Latar Belakang Pendidikan } & \multirow{2}{*}{ Jumlah } \\
\cline { 2 - 4 } & Komunikasi & Non komunikasi & \\
\hline Sangat Loyal & 2 & 2 & 4 \\
\hline Cukup Loyal & 6 & 3 & 9 \\
\hline Loyal & 12 & 1 & 13 \\
\hline Kurang loyal & 4 & 0 & 4 \\
\hline Tidak loyal & - & - & - \\
\hline Jumlah & 24 & 6 & 30 \\
\hline
\end{tabular}

demikian tidak menyalahi peraturan peundangan yang berlaku. Akan tetapi dari sudut pandang Personal Code of conduct, kejadian tersebut sudah dianggap sebagai pelanggaran yang besar. Latar Belakang Pendidikan Vs Profesionalisme

Dari table 1 terlihat bahwa perbedaan latar belakang pendidikan bukan alasan untuk tidak mematuhi peraturan perundangan yang berlaku. Ini seleras dengan pernyataan Soloski

\section{Simpulan}

Nampaknya ada perbedaan pemahaman antara teori dan praktek di kalangan jurnalis mengenai konsep "fakta, obyektif, dan seimbang". Bukti-bukti yang kepada isu tersebut adalah pemenggalan data/informasi pendukung yang tidak cermat, yang mengarah pada hilangnya "konteks", yang mengakibatkan bias makna dan penggunaan nara sumber yang cenderung 
Tabel 2

Perbedaan Latar Belakang Pendidikan dan Loyalitas terhadap Personal Code of Conduct

\begin{tabular}{|l|l|l|l|}
\hline \multirow{2}{*}{$\begin{array}{l}\text { Loyalitas terhadap } \\
\text { Personal Code of } \\
\text { Conduct }\end{array}$} & \multicolumn{2}{|c|}{ Latar Belakang Pendidikan } & \multirow{2}{*}{ Jumlah } \\
\cline { 2 - 4 } & Komunikasi & Non komunikasi & \\
\hline Sangat Loyal & - & - & - \\
\hline Cukup Loyal & 8 & 0 & 8 \\
\hline Loyal & 7 & 2 & 9 \\
\hline Kurang loyal & 9 & 4 & 13 \\
\hline Tidak loyal & - & - & - \\
\hline Jumlah & 24 & 6 & 30 \\
\hline
\end{tabular}

tendensius dan cenderung memperkeruh keadaan

Dilihat dari sudut pandang kode etik jurnalisitik dan peraturan perundangan yang berlaku di Indonesia, pelanggaran yang terjadi tergolong sangat ringan, dan cenderung bias diabaikan. Akan tetapi dilihat dari sisi etikamoral --sebagaimana dimaksudkan dalam penelitian ini-pelanggaran dimaksud termasuk dalam kategori "signifikan". Karena pelanggaran tersebut mengindikasikan rendahnya kesadaran dan penghayatan jurnalis terhadap etika-moral. Apa yang mereka kerjakan, sekalipun benar, seharusnya tidak perlu mereka lakukan.

Perbedaan latar belakang pendidikan tidak serta mempengaruhi loyalitas jurnalis terhadap kode etik profesi maupun peraturan perunsangan yang berlaku. Akan tetapi mempengaruhi mempengaruhi pemahaman mereka mengenai filosofi jurnalisitik, fungsi dan peranan media massa, yang seterusnya berpengaruh terhadap profesionalisme mereka. Ada istilah "peramu berita dan penjual berita"

\section{Daftar Pustaka}

Barroso, Porforio; Lucia Tello; 2006; Movies: a powerful resources of visual literacy in journalism ethics; Research Report.

Crone, Tom; 2002; Law and the Media; Fourth Edition; Focal Press; London; British.
Day, Louis
Alvin; 2000
Ethics in Communication,

Focal Press: London, British. American Society of Newspaper Editors (ASNE):

Statement of Principles, 1996 -2007 Hanson, Gary; 2001, "Learning Ethics: on the job or in the classroom?" The Journal of the Association of Schools of Journalism and Mass Communication, Fall: 2001, pp. 3 - 11

Magnis-Suseno, Franz; 1984; Etika Jawa: Sebuah Analisa Falsafi Tentang Kebijaksanaan Hidup Jawa; PT Gramedia Jakarta 1984.

Merrill, John C.; 1995; Global Journalism: Survey of international communication; Third Edition; Longman: USA. Samuels Annette J.; 2001; "More than Optional Rules for Right Behavior," The Journal of the Association of Schools of Journalism and Mass Communication, Fall 2001, pp. 24 - 26

Soloski, John. 1997. "News Reporting and Professionalism: Some Constraints on the Reporting of News". In D. Berkowitz (ed.), Social Meanings of News. A TextReader, 138-154. Sage Publications.

Sumner David E. 2006, "Teaching Standard in Feature and Magazine Writing Classes". Journal of Magazine and new Media research: Vol. 9, No. 1, Fall 2006.

Ward, Stephen J.A. 2009, “Applied Journalism Ethics" Journalism Ethics for the Global Citizen; School of Journalism 
\& Mass Communication, University

of Wisconsin-Madison, USA.

Zelizer, Barbie. 2004. Taking Journalism

Seriously. News and the

Academy. Thousand Oaks: Sage. 